\title{
Vida em Santidade: modos de ser santo em uma comunidade messiânico-milenarista do sertão baiano (Pau de Colher, 1934-1938)*
}

\author{
Life in Sanctity: ways of being a saint in a messianic-millenarian movement \\ of bahia`s hinterland (Pau de Colher, 1934-1938)
}

Filipe Pinto Monteiro ${ }^{* *}$

\begin{abstract}
Resumo
A proposta do artigo é analisar o fenômeno peculiar da honraria santoral na comunidade messiânicomilenarista de Pau de Colher (Casa Nova, sertão da Bahia, 1934-1938). A partir de um recorte históricocultural e teológico, a investigação será encaminhada no sentido de esclarecer a atuação de uma liderança religiosa, popular e carismática atada a modelos de santidade gestados durante o período medieval no ocidente cristão e transmigrados para o Novo Mundo após os descobrimentos. O texto apresenta documentação inédita e estabelece uma discussão - a partir de obras clássicas e outras referências garimpadas ao longo da pesquisa - em torno da manifestação de santos católicos no interior baiano na década de 30 do século XX. O movimento de Pau de Colher, através da pregação de seus líderes, instituiu um diálogo com uma tradição que remonta às origens do cristianismo; fez crer na ressurreição de personagens como São José, o Carpinteiro e Santa Maria, a Imaculada -, figuras privilegiadas em nosso estudo -; e re-atualizou um conjunto de credos e valores transmitidos pelas mãos de missionários itinerantes e de beatos errantes durante a história do Brasil, revelando um intenso hibridismo entre catolicismo popular e eclesiástico.
\end{abstract}

Palavras-chave: Pau de Colher; santos; sertão; catolicismo; religiosidade popular.

\begin{abstract}
The aim of this paper is to analyze the peculiar phenomenon of the honor saints in the messianicmillenarian community of Pau de Colher (Casa Nova, interior of Bahia, 1934-1938). From a culturalhistorical and theological approach, the research will be directed towards clarifying the role of religious, popular and charismatic leadership tied to models of holiness gestated during the medieval period in the Christian West and transmigrated to the New World after the discoveries. The paper presents unpublished documentation and provides a discussion - from classical works and other references panned throughout the research - around the manifestation of catholic saints in the Bahia's hinterland in the 30s of the twentieth century. The movement of Pau de Colher, through the preaching of their leaders, established a dialogue with a tradition dating back to the origins of christianity; did believe in the resurrection of characters as St. Joseph the Carpenter and St. Mary, the Immaculate - privileged figures in our study -; and re-updated a set of beliefs and values transmitted by the hands of itinerant missionaries and blessed wandering during Brazil's history, revealing an intense hybridization between popular and ecclesiastical catholicism.
\end{abstract}

Key words: Pau de Colher; saints; hinterland; catholicism; popular religiousness.

\footnotetext{
* Artigo recebido em 25 de agosto de 2010 e aprovado em 14 de setembro de 2010. Trabalho realizado com o auxílio financeiro do CNPq.

** Mestre em História Social, linha de pesquisa Sociedade e Cultura, da Universidade Federal do Rio de Janeiro; concluiu bacharelado e licenciatura em História pela Universidade Federal do Rio de Janeiro (2007). Tem experiência na área de Jornalismo e História, com ênfase em História Moderna e Contemporânea, atuando principalmente nos seguintes temas: messianismo, milenarismo, fanatismo, catolicismo popular, religiosidade popular, comunismo, rebeliões e revoltas, Governo Vargas. E-mail: filipemhst@gmail.com
} 


\section{Introdução}

Pau de Colher, movimento messiânico-milenarista que ocorreu no município de Casa Nova, interior da Bahia, entre os anos de 1934 e 1938, possui, hoje, uma respeitável bibliografia. Seu aparecimento em estudos acadêmicos remonta aos clássicos História da Bahia, de Luís Henrique Dias Tavares, cuja primeira edição é de 1959, e Cangaceiros e Fanáticos, de Rui Facó, publicado em 1963. Tratado nessas ocasiões sem qualquer aprofundamento, o episódio só receberá maior atenção em $O$ messianismo no Brasil e no mundo, da socióloga Maria Isaura Pereira de Queiroz, editado em 1965. Os indícios colhidos pela autora se baseavam nos manuscritos, então inéditos, do antropólogo Raymundo Duarte, professor da Universidade Federal da Bahia, cuja primeira exposição sobre o caso se deu em 1969 com suas valiosas Notas preliminares de estudo do movimento messiânico de Pau de Colher. Ambos compartilhavam a valiosa orientação do médico e escritor Thales de Azevedo, formando um pequeno grupo de pesquisa sobre o que era classificado na época de "surtos messiânicos".

Após um breve texto de Duarte sobre o tema em 1972, seguiu-se um intervalo que só foi interrompido em 1991, com um artigo de Maria Alba Guedes Machado Mello, decorrência de suas investigações sobre a história política do Baixo e Médio São Francisco. O primeiro estudo de peso sobre o movimento surgiria apenas quatro anos mais tarde, com a dissertação de mestrado de Maria Cristina Pompa (1995), provavelmente o trabalho mais completo sobre o caso até o momento.

Temos, nos anos subsequentes, algo como uma "redescoberta" do episódio avivada por fatores como o boom da História Oral, que permitiu a coleta de lembranças e reminiscências tanto daqueles que participaram diretamente do episódio, como de seus filhos e netos, tal como fizeram Gilmário Moreira Brito (1999) e Ana Lúcia Aguiar (2008). Pau de Colher também foi alvo de outros estudiosos comprometidos ora com um projeto de ação pastoral e inserção das Comunidades Eclesiais de Base no meio rural brasileiro, ora com uma iniciativa mais ampla de desenvolvimento regional do sertão baiano, caso do

\footnotetext{
1“'Ocorrência de 1938, o surto fanático de Pau-de-Colher, entre Pernambuco e Bahia, vem sendo reconstruído e analisado, por Raimundo Duarte, sob nossa orientação [...]." Ver: AZEVEDO, Thales de. Cultura e situação racial no Brasil. Rio de Janeiro: Civilização Brasileira, 1966, p. 126.
} 
educador Luiz Gonzaga (2002), do teólogo Roberto Malvezzi (2007) e do geólogo Ruy Bacelar (1998).

Os instrumentos teórico-metodológicos para o estudo do caso se multiplicaram na medida em que Pau de Colher abria caminhos variados e oferecia material original para os pesquisadores. Em estudo mais recente, por exemplo, o historiador Francivaldo Mendes da Silva (2008) analisou as diversas narrativas e memórias para a reconstrução da história da comunidade, privilegiando, sobretudo, algo pouco utilizado anteriormente: romances e folhetos de cordel. O último trabalho que detectamos sobre Pau de Colher, merecedor de nota, foi apresentado por Gregg Narber, do Luther College (Iowa - EUA), no XXVIII Congresso Internacional da Associação de Estudos Latino-Americanos, em 2009. A proposta apresentada pelo autor - explorar a incompatibilidade dos movimentos de Caldeirão e Pau de Colher com o projeto de modernização do governo Vargas -, apesar de inovadora, carece de um estudo mais abrangente e detalhado.

O texto aqui apresentado - resultado das pesquisas para o segundo capítulo da nossa dissertação - articula-se com os estudos anteriores, mas diferencia-se pela abordagem de um fenômeno documentado pelas fontes da época: o despontar de uma liderança carismática e popular tomada como sinônimo da perfeição cristã. Ser perfeito, no contexto aqui traçado, era ser puro, pleno, ilibado, imaculado, santo, enfim. A dádiva da honraria santoral outorgada a um grupo privilegiado da irmandade ressuscitou personagens de uma tradição católica que remonta às origens do cristianismo - como São José e Santa Maria -, reatualizou e reinterpretou um conjunto de credos e valores transmitidos pelas mãos de missionários itinerantes e de beatos errantes durante a Colônia, Império e início da República e nos possibilitou fazer relações e analogias que, esperamos, deem sentido a essa experiência única dos sertões baianos.

\section{Lei e disciplina nos sertões}

Estudos preliminares apontaram em Juazeiro do Norte (1889-1934), do Padre Cícero Romão Batista (1844-1934), e na comunidade do Caldeirão dos Jesuítas (19261936), do beato José Lourenço Gomes da Silva (1872-1946), os condicionantes remotos da gestação do movimento de Pau de Colher. O vínculo entre os três fenômenos se deu através 
de um personagem, o enigmático beato Severino Tavares. Severino teve uma trajetória muito particular que permitiu o seu trânsito por diversas cidades e comunidades no sertão nordestino, incluindo Pau de Colher e Caldeirão e, muito provavelmente, Juazeiro do Norte.

Severino era um beato penitente, "secretário" de Zé Lourenço (que por sua vez foi pupilo de Pe. Cícero), incumbido de angariar adeptos para o Caldeirão por todos os rincões nordestinos, uma espécie de relações-públicas do movimento. Ele realizou uma extensa peregrinação por toda a região do Médio São Francisco, passando pelos municípios de São Raimundo Nonato, Remanso, Santo Sé e Casa Nova. Neste último, pregou em Castanheiro, São José, Santa Cruz, Queimadas, Ouricouri, Surdo, Lagoa do Alegre e, por fim, Pau de Colher (POMPA, 1995, p. 48). Dizendo-se a "Terceira Pessoa da Santíssima Trindade", emissário de Padre Cícero e representante de Zé Lourenço, tornou-se conhecido como Padrim Conselheiro (ESTRELA, 1998, p. 33).

Em Pau de Colher, Severino conheceu José Senhorinho Costa proprietário de algumas roças e sítios onde cultivava algodão e mamona, entre outros produtos, vendidos na feira local ou exportados para municípios vizinhos. Senhorinho - futuro líder do movimento messiânico nesta localidade - e sua família adquiriram, desta forma, certo status entre a população. Além da predominância econômico-financeira, o agricultor destacava-se por aptidões e competências ligadas à esfera do sagrado, que aprendera com sua mãe. Era rezador, benzedor e curandeiro, usufruindo assim de um imenso prestigio pessoal. Sua fama chamou a atenção de Severino que manteve com ele forte amizade, ao longo de sua estadia. Após sua partida, determinou que Senhorinho visitasse o Caldeirão (o que ele fez em três oportunidades) e seguisse suas orientações para organizar a comunidade a partir de certas “leis” sagradas (DUARTE, 1972, p. 332).

Senhorinho passou, então, a reunir amigos e familiares, aos domingos, em sua casa, para explicar-lhes os mais variados assuntos religiosos e ler trechos de obras por ele muito admiradas, como a Missão Abreviada e o Caminho Recto e Seguro (DUARTE, 1972, p. 16). As informações sobre o período inicial de concentração de fiéis ao seu redor são muito escassas e se limitam, em quase sua totalidade, aos testemunhos de sobreviventes colhidos nas décadas de 80 e 90 . Isso se deve ao fato de que as principais investigações jornalísticas e os documentos privados sobre a comunidade foram produzidos durante e após sua 
destruição por tropas militares em 1938, quatro anos após o início da concentração no lugarejo.

O médico Raimundo Estrela, responsável pela assistência médica às tropas que participaram da campanha contra Pau de Colher, diz, em seu livro de memórias, que os moradores do lugar usavam roupas pretas - em sinal de luto pela morte de Padre Cícero (1934) - e seguiam os conselhos de Severino, transmitidos a Senhorinho: não comer carne, alimentar-se de milho, feijão e farinha, não usar bebidas alcoólicas, pagar as dívidas e vender seus bens, renunciar aos gozos terrenos, não cumprimentar as pessoas encontradas pelos caminhos, praticar rezas, submeter-se a sacrifícios e flagelações (ESTRELA, 1998, p. 33). Estas eram algumas exigências da Lei do Padrim Conselheiro, que todos deveriam seguir rigorosamente, sob pena de punição.

Estrela provavelmente se baseou nas memórias, publicadas em livro, do Capitão Optato Gueiros, comandante da Brigada Militar de Pernambuco, que atuou em Pau de Colher (GUEIROS, 1952). Reportagem da Gazeta de Alagoas também cita outras ações do beato que correram o povoado:

\section{CEM CONTOS DE RÉIS DE DÁDIVAS}

Em Pau de Colher o beato Severino conseguiu arrecadar cerca de cem contos de réis dos fanáticos, pois a esses vendiam terras que dizia serem do céu, aconselhando mais que eles não combatessem com pessoa alguma e nem dessem os seus filhos para baptizar com os padres, pois só a elle Severino, cabia este poder como mandado de Deus. ${ }^{2}$

Duvidamos que Severino tivesse, de fato, arrecadado dinheiro entre o povo e lhe vendido terrenos, já que outros indícios dão conta de um abandono voluntário de bens materiais - incluindo terrenos e propriedades - tanto por parte do beato, quanto dos fiéis. O capitão Perouse Pontes, comandante da $2^{\mathrm{a}}$ Companhia de Fuzileiros do $19^{\circ} \mathrm{BC}$, de Salvador, uma das volantes enviadas à Casa Nova, reitera outros pontos em entrevista:

Há muito tempo, segundo dados que colhi, reuniam-se sertanejos atraídos por um tal de Severino, que se dizia enviado do beato Lourenço, em Caldeirão, com o intuito de, através da reza do terço, da flagelação, redimir-se do pecado conquistando a salvação da alma. Os fanáticos, que cada dia que passava iam aumentando assustadoramente, organizaram-se.

\footnotetext{
${ }^{2}$ As incursões do beato Zé Lourenço através dos sertões nordestinos. Gazeta de Alagoas, Maceió, 27 de julho de 1938.
} 
Pela manhã, vestiam roupas de zuarte e à noite, vestes pretas, alguns conduzindo bornais a tiracolo e grandes cruzes. (ESTRELA, 1998, p. 121).

Em seu relatório final sobre os eventos ocorridos em Pau de Colher, enviado ao Secretário de Segurança Pública de Pernambuco, Etelvino Lins, e publicado depois no Diário de Pernambuco, Optato Gueiros também se refere à tal "lei” do beato Severino:

\section{INSISTENTES CONVITES PARA RENDIÇÃO}

Durante quarenta e duas horas de combate, não deixei de convidal-os á rendição, offerecendo-lhes todas as garantias: a resposta, porém, era sempre negativa e, em gritos, declaravam que não se entregariam, e que tinham o prazer de morrer, em virtude de contarem com a salvação da alma. [...]

1.600 FANÁTICOS

Do dia 3 de janeiro deste anno, os assaltos ás fazendas com o trucidamento de familias inteiras, começaram, de modo alarmante e revoltante. Os cadáveres eram incinerados, e tive occasião de ver diversas piras extinctas com ossadas humanas confundidas com carvão e cinza. O mais horrível de tudo isso era o contemplar-se um pé aqui, u`a mão acolá de creancinhas que tiveram a sorte dos pais. Todos os habitantes daquellas fronteiras que não aceitassem a lei deveriam morrer ${ }^{3}$

Optato provavelmente pintou um quadro com cores muito carregadas para impressionar seu superior e justificar o bárbaro massacre que se desenrolou de janeiro a fevereiro de 1938 e deixou algo em torno de 400 vítimas fatais, entre homens, mulheres, crianças e idosos. O que nos chamou a atenção é a menção à "lei" no final do trecho, citada também em outras fontes. Segui-la, honrá-la, reverenciá-la e, sobretudo, suportá-la e temêla era sinônimo de salvação e redenção para aqueles sertanejos. Eduardo Hoornaert, em uma de suas investigações sobre o catolicismo popular, diz que o nordestino identifica o termo "lei" na instituição da Igreja. Esta impõe uma disciplina, um conjunto de regras e ensinamentos que, embora indecifrados para a grande maioria, devem ser apreciados e respeitados. $\mathrm{O}$ autor se refere à Igreja da hierarquia tridentina, uma estrutura que prima pelas "obrigações ligadas aos sacramentos, à celebração da santa missa, à organização da catequese" (HOORNAERT, 1969, p. 584).

\footnotetext{
${ }^{3} \mathrm{O}$ vulto que tomavam as recentes actividades dos fanáticos de José Lourenço. Diário de Pernambuco, Recife, 8 de fevereiro de 1938.
} 
Segundo esse autor, a lei católica, imposta de cima, exterior à personalidade e angústias mais urgentes dos fiéis, seria o oposto do que os sertanejos entenderiam de forma generalizada por religião. Esta última, sim, exprimiria a vida íntima, as convicções pessoais, os valores e sentimentos de cada um. A diferenciação é importante para nossa análise porque, se por um lado, o habitante de Pau de Colher possuía a sua religião, fundamentalmente católica e popular, claramente lhe faltava uma lei, isto é, um complexo de idéias teológicas, capaz de impor deveres e obrigações diárias para consigo e para com a comunidade. Essa situação seria decorrência de um fenômeno, exaustivamente analisado em obras anteriores, que tem origem nos tempos coloniais e se estendeu até os primeiros anos da República: a frágil institucionalização da Igreja no Brasil. Sobretudo nas regiões mais distantes dos sertões nordestinos, esse é um fato inegável, como demonstram fontes de época. Em Pau de Colher, os catingueiros só tinham algum contato com representantes do catolicismo oficial nas datas religiosas tradicionais - como Natal, Páscoa e Ano Novo - em que a população migrava até a sede do município, Casa Nova, ou quando, excepcionalmente, os vigários ambulantes percorriam o interior em desobriga para celebrar missas, casamentos e batizados. ${ }^{4}$

A gente do sertão, acostumada a viver longe do padre, aprendeu a prescindir de sua presença. "Isso não significa reconhecer-se desvinculada da hierarquia, nem muito menos mostrar-se infensa a ela" (COSTA E SILVA, 1982, p. 23), pondera Cândido da Costa e Silva. Textos e formulações teóricas, transmitidos pela cultura ágrafa do povo do sertão, foram absorvidos, mas sofreram um processo de edição, omissão e aditamentos nem sempre coerentes com a ortodoxia católica. Esta, composta de linguagem erudita, frases em latim e abstrações teológicas, adaptou-se - ou foi adaptada, difícil dizer - ao devocionário popular e parece ter sido esse, a princípio, o rico material utilizado por Severino e Senhorinho para impor a sua própria lei, um regime religioso que guarda profundas semelhanças com esse débil catolicismo institucional, embora tenha incorporado crenças e valores que mudaram, por completo, sua fisionomia.

\footnotetext{
${ }^{4}$ Segundo Hoornaert, esse problema, verificado ao longo da história, teve um momento de exceção durante o século XVIII, em Salvador, na Bahia, onde pôde ser constatado um excessivo numero de clérigos, atraídos pelas regalias governamentais, pelos rendimentos advindos dos testamentos, pelas esmolas pagas para celebração de missas e pela invejável posição social do pároco na sociedade baiana. Ver: HOORNAERT, Eduardo. As relações entre Igreja e Estado na Bahia colonial. Revista Eclesiástica Brasileira, vol. 32, fasc. 126, pp. 282-286, junho de 1972.
} 
A primeira conclusão a que chegamos é que o que foi classificado à época como fanatismo religioso não existiria sem uma aproximação com a "lei dos padres". Segundo Hoornaert:

O contacto com a mentalidade popular, pelo menos no setor restrito aqui analisado, mostra como o fenômeno do "fanatismo religioso" é frequentemente mal interpretado, quando atribuído à ignorância popular. As pessoas não são tão fanáticas quando não entram na área de maior influência da "lei", tanto católica quanto crente. A lei cria o fanatismo. (HOORNAERT, 1969, p. 587).

Costa e Silva, em análise semelhante, entende que a ação pastoral nas regiões rurais do sertão nordestino a partir do século XIX - as aclamadas missões populares - contribuiu para a acentuação de um catolicismo "colérico", típico de manifestações como Pau de Colher. Para o autor, as dificuldades extremas do serviço religioso nessas regiões, a necessidade de adaptação do currículo tridentino àquelas distantes paragens, o constante sentimento de superioridade dos missionários para com aquela gente ignorante, as relações pessoais, baseadas no autoritarismo e na perversidade do mandonismo local, obrigavam os padres a submeter a população à obediência cega aos sacramentos, massificando o crente, sem respeitar-lhe um acolhimento livre e consciente da doutrina, inculcando-lhe uma visão de excepcionalidade da disciplina religiosa. Diz ele:

Basicamente foram as missões itinerantes as responsáveis pela tarefa da doutrinação, numa ótica de acentuado rigor penitencial e escatologia apavorante. Esses aspectos, provavelmente, concorreram na formação singular do viver cristão, a um só tempo autônomo e supletivo, dependente e conservador, seletivo e reinterpretativo. (COSTA E SILVA, 1982, p. 15).

O catequismo missionário na Bahia, promovido principalmente pelos lazaristas franceses e capuchinhos italianos, estimulava o fervor popular, acentuando aspectos em torno da gravidade dos pecados mortais e a ameaça latente do castigo divino. Se por um lado os padres romanizados eram instruídos a combater as superstições dos fiéis, por outro reafirmavam, pelos motivos já citados acima, entre outros, a "salvação pela conversão, a existência do inferno e o Juízo Final” (MATTOSO, 1992, pp. 408-409). Havia, portanto, 
certa harmonia entre os temas propostos pelos sacerdotes e as crenças populares, ambas extremamente penitenciais, moralizadoras e providenciais.

Engana-se, entretanto, quem pensa que a Igreja não se preocupava com essa situação sui generis do catolicismo no meio rural do nordeste brasileiro. Os desvios de comportamento dos padres eram creditados à combinação nefasta de dois fatores: a vastidão do Brasil continental e o caótico desenvolvimento da civilização colonial (SERBIN, 2008, p. 28). Com esse diagnóstico em mãos e mentes, a resposta de Roma foi fortalecer os padrões tridentinos da formação eclesiástica, principalmente depois do Concilio Vaticano I (1869-1870), que teve, pela primeira vez na história, participação de bispos brasileiros. ${ }^{5}$ Era o momento de implantação de uma disciplina austera, severa e inflexível, que atingiu, sobretudo, os seminários vicentinos, mas que nos rincões do país, não conseguiu se desvincular de uma religiosidade marcada pela expiação religiosa, pelas festividades de santos e pela ameaça constante do fogo e do enxofre àqueles que a ela não se submetessem (SERBIN, 2008, p.90).

A manutenção de um disciplinamento rígido e punitivo e o respeito cego à hierarquia marcou as comunidades interioranas, e a estruturação da irmandade em Pau de Colher não poderia ter sido de outra forma. Afinal, "inscrita no catolicismo popular existe uma interiorização do catolicismo oficial ou clerical [...], uma absorção do modelo hierárquico" (HOORNAERT, 1979/9, p. 55). Senhorinho, investido da liderança suprema, era o "cabo-verde", "falante", "bem apessoado", que sabia "dar entrada e saída de tudo", assíduo freqüentador das romarias do Juazeiro do Norte e do Bom Jesus da Lapa (MELLO, 1991, p. 56). Logo abaixo estavam seus auxiliares diretos e muito citados nas fontes quando de suas prisões, selecionados com base nas relações de parentesco e amizade: sua mulher, Ana Mariinha; seu sobrinho, José Camilo; seu primo, João Damásio; Pedro Costa (irmão de Camilo); Pedro Benvenuto (rico fazendeiro e comerciante, principal fornecedor de mantimentos para o grupo); Ângelo Cabaça; João Baraúna; José Rozendo; Simplício; Zé Vicente e Januário (ESTRELA, 1998, p. 119). Esse era o núcleo central, a cúpula do

\footnotetext{
${ }^{5}$ O Concílio Ecumênico Vaticano I ocorreu 300 anos após o Concílio de Trento e tinha por meta atualizar o catecismo tridentino, implementando medidas como a infalibilidade papal e melhorando a formação eclesiástica dos sacerdotes com a criação ou reforma de seminários. Ver: RUBERT, Arlindo. Os bispos do Brasil no Concílio Vaticano I (1869-1870). Revista Eclesiástica Brasileira, vol. 29, pp.103-120, março de 1969.
} 
movimento, por assim dizer, que respondia apenas a Senhorinho e chegou a ter sob seu controle mais de mil integrantes.

Vários autores afirmam que, da mesma forma que Zé Lourenço e Severino, Senhorinho era capaz de fazer previsões sobre um futuro apocalíptico, cercado de dores e sofrimentos e promover manifestações milagrosas, como o advento da chuva. Em determinado momento, teria Senhorinho mudado de "fala", entrado em transe, o que era prova de sua condição extraordinária. O Coronel Maurino Cezimbra Tavares, comandante do Esquadrão Motorizado da PM baiana, corpo militar que interveio na comunidade, em trabalho apresentado ao Instituto Baiano de História da Medicina, relatou que tinham os moradores do lugar

Pendido aos pescoços cordões com a medalha tendo em um dos lados a efígie de Padre Cícero. Estavam vestidos de roupa preta, amarrada à cintura, com cordões com cinco nós. Eram muitos cacetes e cruzes ao lado de seus corpos. Os informantes revelaram que os seguidores acompanhavam Senhorinho cantando e repetindo os textos dos benditos embelezados pelas prédicas bíblicas cuja leitura era feita ao amanhecer e à tarde, à hora da Ave Maria (TAVARES, 1954).

Os objetos não eram apenas símbolos, representavam sentimentos, aspirações, desejos que, capturados por esses líderes, eram decodificados e traduzidos em uma linguagem católica, porém popular, e não erudita. Como será demonstrado detalhadamente a seguir, parece que a melhor forma de realizar esse trabalho de evangelização matuta era apelar aos santos católicos, velhos íntimos da população sertaneja, ora ocupando espaço nos oratórios familiares e ermidas comunitárias, ora sendo invocados nas festas religiosas anuais (FREYRE, 1980, pp. 246-249).

\section{São José e Santa Maria}

A comunhão com os santos se tornou a principal prática de fé do catolicismo implementado na Bahia. Era uma concepção religiosa em que se estabelecia um intercâmbio entre o céu e a terra, pelo qual os sertanejos pretendiam alcançar a garantia de uma vida feliz no além-túmulo através de intercessores poderosos (AZZI, 2001, p. 202). As leituras à hora de Maria, mencionadas na citação anterior de Cezimbra Tavares, podem 
indicar mais do que um hábito corriqueiro. A devoção mariana parece ter predominado na comunidade. Reportagem do jornal $O$ Pharol confirma nossa hipótese:

Aguardando os acontecimentos, transcrevemos, para conhecimento dos leitores, a curiosa saudação dos fanáticos: "Louvado seja Nosso Senhor Jesus Christo, Alto Celeste do Amor. (Resposta) Para sempre seja louvada nossa Mãe Maria Santíssima, Deus Onipotente e a Luz de Nosso Senhor". ${ }^{6}$

A adoração à Virgem Maria teve forte impulso no Ocidente cristão durante a Idade Média em vista do aumento da importância das mulheres no interior das famílias nucleares. No medievo tardio, particularmente nos séculos XII e XIII, deu-se uma expansão do culto mariano entre as ordens mendicantes como os franciscanos e carmelitas, que associam a devoção do Menino Jesus à Imaculada Conceição (VAUCHEZ, 1995, p. 134). No início da Idade Moderna, ainda que a figura feminina fosse associada ao demônio, propensa ao pecado e à profanação, a devoção à Santíssima cresceu não apenas por ser ela uma personagem exemplar e idealizada, ou seja, não relacionada diretamente ao "segundo sexo", mas também por ter servido como arma contrarreformista da Igreja que desejava humanizar a figura de Cristo colando sua imagem ao seu parentesco humano mais próximo. A consolidação da idolatria marial foi excepcionalmente forte em Portugal e está ligada à fundação do reino por D. Afonso Henriques, que recebeu da santa uma dádiva e a fez padroeira do país. Sua presença, portanto, em terras brasileiras seria consequência do desenrolar dos descobrimentos: "Ideal feminino católico, o culto à Virgem tornar-se-ia a bandeira da conquista espiritual portuguesa na sua expansão ultramarina" (VAINFAS e SOUZA, 1999, p. 204).

$\mathrm{Na}$ Bahia, a presença da Santa Maria Maior se difundiu desde os tempos coloniais recebendo diversas denominações ao longo dos anos. Erguida em Vila Velha por volta de 1535, a primeira ermida dedicada a Nossa Senhora da Graça se tornou grande centro de devoção. Os jesuítas, por sua vez, rogaram a Nossa Senhora da Ajuda proteção durante a construção da cidade de São Salvador, dedicando-lhe espaço de veneração na matriz da cidade. No século XVIII, Nossa Senhora das Candeias apareceu no Recôncavo e, no XIX,

\footnotetext{
${ }^{6}$ De novo em acção os fanáticos do beato Lourenço! O Pharol, Petrolina, 18 de junho de 1938.
} 
durante o festejado ciclo do Bonfim, era aclamada como Nossa Senhora da Guia, orientadora de Jesus na meninice (AZZI, 2001, pp. 50-55; 162-167; 305-312).

Nos princípios do século $\mathrm{XX}$, as congregações marianas se estabeleceram definitivamente em território baiano pelas mãos dos jesuítas e dos maristas e ganharam espaço no início dos anos 30, culminando com a realização do $1^{\circ}$ Congresso Mariano da Bahia, em 1937 (AZZI, 2001, pp. 66-67; 358-361). Como muitos dos sacerdotes formados nos seminários soteropolitanos eram enviados aos sertões, tudo leva a crer que a mariologia extrapolou as fronteiras urbanas junto com outras manifestações e expressões religiosas. Em Pau de Colher, alguns personagens da história receberam nomes de santos, entre as quais se encontra a Puríssima, como demonstra Optato Gueiros: "Entre os fanáticos havia os que já tinham alcançado o gráu de santidade e eram tratados por santos. Encontravam-se por lá os seguintes seres angelicais: São Arão, São Moisés, São José, São João, Santa Inês, Santa Maria e assim por diante.” (GUEIROS, 1952, p. 170).

Optato se refere a outros santos, mas nos deteremos, por ora, na figura de Maria, que, segundo teólogos, foi o instrumento do poder criador de Deus por ter concebido o Menino Jesus sem intervenção humana direta. Esta é a concepção virginal de Maria Lactante, presente, por exemplo, nos evangelhos de Mateus e Lucas (BOFF, 2004, pp. 4070). Ao participar do Mistério da Encarnação, Maria foi a testemunha, por excelência, da Graça Divina. Em Pau de Colher, entretanto, descobrimos que o nome da Gloriosa está diretamente associado não ao nascimento de Jesus, como era de se esperar, mas, sim, ao momento de seu suplício, à forte imagem do filho na Cruz, visto que Ana Mariinha, esposa de Senhorinho, era tida como "minha madrinha Santa Cruz":

\footnotetext{
Pau de Colher um pequeno Canudos

Uma trágica coincidência - Negando Euclydes da Cunha - Homens trabalhadores transformados em feras - Sinhorinho, o "São José" e sua mulher a "Santa Cruz" - As primeiras victimas - A insânia se transforma em tragédia. ${ }^{7}$
}

Estudos teológicos mostraram que Maria recebe grande destaque quando está aos pés da Cruz, como bem coloca o apóstolo João (CASALEGNO, 1989, p. 104). Esse fato confirma que a importância da Preservada vai além do momento da concepção. Ela é o elo

\footnotetext{
${ }^{7}$ Cf. Pau de Colher, um pequeno Canudos. Estado da Bahia, Salvador, 22 de fevereiro de 1938.
} 
entre o nascimento de Jesus e sua crucificação; a sua presença nesse momento excepcional é um caminho para se explicar a centralidade da imagem da Cruz na doutrina católica e, consequentemente, seu apelo imagético em Pau de Colher. No ponto alto do drama vivido pelo Salvador, na hora suprema da glória e do martírio, "a luz da Cruz ilumina o mistério de Maria e a revela como Mãe espiritual dos Discípulos" (BOFF, 2004, p. 84). Ela é, afinal, Maria Cheia de Luz. Sua exaltação está, portanto, intimamente relacionada à exaltação da Cruz, o que explicaria o aparecimento de uma "Santa Cruz" rediviva em Pau de Colher.

Segundo Mehlmann (1953), há uma passagem na Bíblia que sugere quatro diferentes possibilidades de identificação da personagem incorporada por Ana Mariinha: "E junto à cruz de Jesus estava sua mãe, e a irmã de sua mãe, Maria mulher de Cleópas, e Maria Madalena." (Jó 19: 25). Como Ana era casada e vivia na mesma casa que Senhorinho - tomado como São José pelos fiéis - presume-se que ela fosse, portanto, a Perpétua, com quem José havia contraído matrimônio e com quem Jesus passara a infância na história real.

A celebração a José, por sua vez, tem origens na Igreja Oriental e é marcada pela festa ao padroeiro, oportunidade em que se dava a leitura da História de José o carpinteiro, apócrifo do Novo Testamento. ${ }^{8}$ No Ocidente, o culto ao santo só aparece com força no século XII, trazido das bandas orientais pelos cruzados, porém permanece, por longo tempo, “à sombra e à margem da reflexão teológica. Somente a tradição popular cultivoulhe fielmente a memória" (BOFF, 2005, p. 110). Aceito oficialmente no seio da instituição pelas mãos do papa Sixto IV, no século XV, José ficou conhecido como Patriarca da Igreja, título este que seria concedido apenas em 1887, por obra do papa Pio IX (SILVA, 1988, pp.133-146).

Invocado em Portugal, tornou-se, no Brasil, típico orago familiar, visto como exemplo de "homem bom" e "chefe de família". Seu caráter humilde e trabalhador pode nos indicar outras similitudes com a figura de Senhorinho. Afinal, ambos eram "operários", homens dedicados a um ofício braçal e que dependiam deste para sua sobrevivência. Senhorinho era lavrador e José, carpinteiro. Além disso, um e outro eram pessoas simples,

\footnotetext{
${ }^{8}$ Este não é o único apócrifo sobre São José, mas é o mais rico em informações. Provavelmente escrito no Egito, no século IV ou V, trata-se de uma longa narrativa de Jesus sobre seu pai feita aos apóstolos no Monte das Oliveiras. Ver: BOFF, Leonardo. São José: a personificação do pai. Campinas: Verus Editora, 2005, p. 106.
} 
rudes e de poucas letras, fato que não os impedira de possuírem grande conhecimento das coisas religiosas e de terem, acima de tudo, sido escolhidos por Deus para sua missão salvífica na terra. No Brasil, a devoção ao "Santo Pai" caminhou muito próxima à da "Santa Mãe", ambas refletindo o caráter de pureza das figuras piedosas: "Deus-pai transmite a vida sem perda de integridade e José, Esposo-Virgem, representa ao vivo a paternidade virginal do pai eterno" (PAIVA, 1954, p. 5).

A interpretação clássica, que perpassa todos os estudos sobre o casal de santos, demonstra que, tanto litúrgica quanto popularmente, a Igreja é tratada como uma Família Sagrada, composta por Jesus e seus apóstolos, tendo Maria e José como figuras de proeminência e, este último, como líder espiritual, ao qual os outros deviam obediência: “Todos estão submissos a São José e o veneram depois que Maria e o próprio Jesus lhe obedeceram em Nazaré. Jesus o sol, Maria a lua, junto ao nosso José da nova Lei! O maior dos santos é, pois, o mais querido e venerado dos próprios santos" (BRANDÃO, 1957, p. 127). Em Pau de Colher, a nova lei de Senhorinho, à semelhança das comunidades cristãs primitivas, também foi implementada, e todos respondiam aos seus mandamentos, aguardando a salvação eterna e aspirando ansiosamente por ela. Relato publicado no Estado da Bahia sobre os que tombaram em meio ao ataque à comunidade nos dão uma idéia:

Quarenta e duas horas de fogo, depois de um brutal combate de corpo a corpo, ceifaram centenas de vidas, na sua maioria de irresponsáveis, mulheres e crianças. $\mathrm{O}$ ataque, porém, não os acovardou. Aos gritos de "Chegou a Salvação" e "Viva S. José" mulheres se atiravam sobre as metralhadoras que vomitavam fogo, cortando os corpos ao meio. [...] Mulheres mortalmente feridas, interrogadas pelos soldados, pediam a morte, pois, ella traria a salvação promettida e desejada. ${ }^{9}$

O texto acima, bem como os que observamos em outros periódicos, denota que os membros do grupo, ao serem atacados, pareciam não se importar com a morte iminente, pois José, o Patriarca havia lhes prometido a salvação. Em reportagem do Correio do Bonfim, essa afirmação faz sentido: "Os feridos, quando a morte se avisinhava, diziam: ‘está chegando a salvação’”. E quando lhes perguntavam por algum morto na lucta, diziam:

\footnotetext{
9 “Foi um esbagaçamento horrível! Nunca vi igual!”. Estado da Bahia, Salvador, 23 de fevereiro de 1938.
} 
"Salvou-se". Era crença, entre elles, adianta o confrade, de que os que morriam estavam "purificados". 10

A purificação, fosse através de comportamentos exemplares, rezas ou sacrifícios, significava que essas pessoas se consideravam, obviamente, impuras, sujas, contaminadas, isto é, pecadoras e ninguém melhor do que São José para livrá-las do mal. Considerado também como o patrono dos agonizantes, São José oferecia abrigo aos mais desesperados, às almas mais atormentadas, aos espíritos mais aflitos, um verdadeiro refugium peccatorum, refúgio dos pecadores. "Quem é mais necessitado e miserável que o pecador? Aos pecadores, sim, haveríamos de recomendar: Ite ad Joseph! Ide a José!” (BRANDÃO, 1957, p. 122).

O culto aos santos pode ser interpretado como um exemplo da ausência da disciplina católica nos sertões, ou, em outra perspectiva, da presença de uma nova regulamentação cristã popular. Se, por um lado, os catingueiros veneravam figuras de destaque da Igreja, por outro, se descuidavam dos cultos litúrgicos - base da disciplina, da lei -, para eles incompreensíveis, e o que era mais perigoso, tratavam seus pares como personagens santificados, algo condenável pelos sacerdotes. Em última análise, reinterpretavam os códigos e ordenações católicas em seu próprio entendimento, trazendolhes novas conotações.

\section{Modelos hagiográficos}

Para uma compreensão adequada e convincente da forma como se gestou a adoração aos santos católicos em Pau de Colher e suas consequências, é preciso recorrer à hagiografia, gênero literário que trata dos santos, sua história de vida e sua devoção. Aqui, tentaremos, na medida do possível, remeter-nos sempre às situações identificadas em Pau de Colher que, iluminadas por esses estudos, adquirem um sentido lógico, coerente, racional até.

Há de se fazer uma rápida observação. O termo hagiografia ou hagiologia, como também era conhecido quando surgiu, no século XII, refere-se a dois campos distintos do conhecimento. O primeiro tem origem nos tratados milagrosos, calendários litúrgicos,

\footnotetext{
${ }^{10}$ Os fanáticos de Pau de Colher. Correio do Bonfim, Salvador, fevereiro de 1938.
} 
catalogus sanctorum, martirológios, entre outros registros que remontam às raízes do cristianismo e que proliferaram durante a Idade Média, sendo a Península Ibérica importante polo de produção desse rico material (SILVA, 2001, p. 135-172). Suas principais características eram o privilégio dispensado aos atores do sagrado (santos) e à sua respectiva edificação (exemplaridade). Em outras palavras, aqueles que assim procediam não estavam preocupados com "aquilo que passou", como o fariam historiadores, mas sim com "aquilo que é exemplar" e significativo (CERTEAU, 2000, p. 266-267).

O segundo se deu como uma reação a essa perspectiva inicial, e coube a um grupo de jesuítas belgas, como Jean Bolland (autor de Acta sanctorum, de 1643), que introduziu a crítica historiográfica ao estudo santoral. Estabelecia-se uma "pesquisa sistemática dos manuscritos, classificações das fontes, transformação do texto em documento" (CERTEAU, 2000, p. 268); em suma, criava-se uma base científica para a concessão da honraria santoral "concebida como o único meio de defender o culto dos santos contra os críticos" (GAJANO, 2002, p. 462). A erudição eclesiástica assentou, portanto, as bases da orientação histórico-crítica hagiológica, que se tornou, ela própria, um ramo da historiografia, influenciando, décadas depois, trabalhos de especialistas como Le Goff, Certeau, Vauchez, Huizinga, entre outros dos quais lançaremos mão aqui.

No Brasil, a produção acadêmica dedicada à investigação hagiográfica é relativamente recente, se comparada com o que foi produzido na Europa. Talvez isso se deva não apenas ao fato de que, na América Portuguesa, relatos dessa natureza não foram tão abundantes, mas também porque a primeira canonização de um santo brasileiro pelo Vaticano só tenha se dado em 2007, com Antônio de Santana Galvão (1739-1822), o Frei Galvão. Ressaltamos esse ponto, pois o estabelecimento do cânon em torno do santo foi um dos motivos que mais estimularam o escrito hagiológico cristão em seus primeiros tempos.

Durante a maior parte da Idade Média, o culto aos Mártires foi a maior fonte de prestígio da Igreja. Nele se delineava um tipo de relação entre o santo venerado e a sua clientela que se prolongará por séculos e regulará qualquer atividade devocionária: "lealdade do protegido, "amizade" e dever de protecção por parte do patrono em relação a quem a ele se recomendou" (VAUCHEZ, 1989, p. 212). Paralelamente desenvolveu-se, na Igreja Oriental, um modelo de santidade que se difundiu rapidamente por todo o mundo 
cristão: o ideal do homem de Deus (vir Dei) que não aceita os valores dominantes de sua época para se refugiar no claustro e dedicar a vida à penitência e mortificação (VAUCHEZ, 1989, p. 213). Certo número de sinais, aos olhos da multidão, atestava que o santo renegava tudo o que era reconhecido pelas sociedades da época e adotava uma vita passiva. Recusa à alimentação à base de carne, ovos e derivados de leite, abstenção das relações sexuais, negação do valor do dinheiro, entre outros prazeres mundanos (VAUCHEZ, 1987, pp. 289290).

Em Pau de Colher, premissas como as descritas acima dirigiam a vida cotidiana do povoado. A alimentação só podia ser à base de milho, colocado em depósitos e paióis, farinha, guardada em sacos ou caixões e feijão, armazenado em vasos de flandres pintados de piche (DUARTE, 1997, p. 129). Aos homens e mulheres não era permitido ter relações de conotação sexual de qualquer natureza e ambos os sexos viviam apartados no reduto (DUARTE, 1997, p. 129; POMPA, 1995, p. 65). Para ser admitido na comunidade, também era necessário se desfazer de seus bens, incluindo propriedades e reservas de dinheiro, que não circulava entre os fiéis. Esta última exigência era ordem de Severino, como pudemos constatar em uma carta de Pe. Cícero, na qual o sacerdote responde a um pequeno proprietário que pensava em vender suas terras, pois assim Severino havia aconselhado:

Joaseiro, 5 de setembro de 1932

Amigo Sr. Félix Virgulino de Sena

Recebi sua carta de 23 de agosto e passo a respondê-la. Esse Severino Tavares que andou ahi inquietando a sua família, é um pobre maluco, a quem ninguém deve ligar importância sobretudo para dar crédito às asneiras que anda pregando no meio do povo ignorante. Nunca lhe dei e nem podia dar autorização para andar se prevalecendo de meu nome para coisa alguma. Peço-lhe, portanto, como especial obséquio que, não só aos membros da sua família que se deixaram influenciar por esse pobre homem, como a todos os que com ele convierem ahi, diga, em meu nome, que elle é simplesmente um maluco, em quem ninguém deve acreditar. Quanto ao senhor, aconselho-o a não vender absolutamente as suas propriedades, nas quais deve continuar a trabalhar, com os seus filhos e netos. Se algum destes se obstinar em continuar a dar crédito às asneiras de Severino Tavares, mande este até aqui para eu, de viva voz, lhe reproduzir o que digo nesta carta e convencê-lo de que deve, em obediência aos seus desejos, permanecer ahi, trabalhando como o sr. na terra onde nasceram e se criaram. Pe. Cícero Romão Batista (SILVA, 1982, pp. 180-181) 
Havia uma lógica nesse comportamento. Vivendo uma vida de privações, evitando as distrações do mundo profano, os santos se aproximavam definitivamente da natureza e acreditavam ter a capacidade de dominá-la, pondo os seus poderes a serviço dos homens (VAUCHEZ, 1987, p. 290). Assim fazia Senhorinho ao trazer chuva para a caatinga ou, de forma oposta, como predizia seu companheiro José Camilo, provocando secas devastadoras. Este último teria prometido ao ser preso:

Interpelado pelo sargento Borges, que commandava o volante, respondeu: - "Isso não é nada. Os annos de 1938 e 39 serão annos de soffrimento e martyrios. Em 1940 uma grande e impressionante secca atingirá o povo do sertão. Vocês é que vão soffrer demasiadamente, pois não conhecem nada da palavra do nosso mestre". ${ }^{11}$

O padrão de santidade importado do Oriente parece ter deixado marcas mais duradouras do que poderíamos conjecturar, levando em conta o fato de que estamos falando dos sertões baianos da primeira metade do século XX. Testemunho do capitão Optato nos chamou a atenção por um pequeno detalhe na última linha: "Interroguei alguns prisioneiros e elles me contaram como viviam no reducto. Andavam todos uniformisados e, á noite, vestiam roupas pretas, sempre armados de cacetes. Traziam nas vestes duas cruzes desenhadas, á semelhança da Igreja Orthodoxa."12

Os integrantes de Pau de Colher confeccionavam grandes cacetes, longos varapaus de madeira, marcados com uma Cruz dupla, utilizados contra os que não queriam participar da irmandade ou que "apresentavam sintomas de transformação em fera" (DUARTE, 1972, p. 334). Passaram a ser apelidados de "caceteiros". Talvez seja exagero de nossa parte enxergar no trecho acima citado características de um modelo santoral bizantino, ou seja, oriental. Mas o fato é que, tanto nas vestes, quanto nos cacetes, a Cruz dupla era representada. Um comportamento que se traduzia pela necessidade de personificação e encarnação do Divino e uma intervenção direta do sobrenatural na vida quotidiana.

Nos últimos séculos do período medieval, gradativamente, "foi ocorrendo uma apropriação clerical sobre o culto dos santos" (GAETA, 1999, p. 62), e a Igreja passou a criticar aqueles que se dedicavam apenas a contemplar o "mistério infinito de um Deus

\footnotetext{
${ }^{11}$ Preso José Camillo chefe supremo dos fanáticos. Estado da Bahia, Salvador, 17 de fevereiro de 1938.

12 Possível infiltração do communismo nas hostes fanáticas do nordeste. O Jornal, Rio de Janeiro, 1 de fevereiro de 1938.
} 
diferente do homem e inacessível" (VAUCHEZ, 1989, p. 218). As aspirações religiosas da época valorizavam o servo que, pelo empenho pessoal, seguisse e imitasse em sua vida o exemplo e a plenitude de Cristo, os sequela Christi.

Este é um ponto da análise que muito nos interessa, visto que o exemplo de santidade caracterizada pela renúncia ao mundo, pelas provações sofridas em nome do amor a Deus e pela valorização de um ascetismo que torna o homem semelhante a Jesus transborda as fronteiras eclesiásticas e se propaga entre a população rural e urbana (principalmente do Mediterrâneo), não respeitando fronteiras de classe social e influenciando categorias as mais diversas, tais como reclusos, errantes, benfeitores, monges etc. (VAUCHEZ, 1989, p. 220).

A Igreja de então era um tanto imprudente quanto ao iminente perigo de "deterioração da fé, causado pela imaginação popular vagueando livremente nos domínios da hagiologia” (HUIZINGA, [s.d], p. 171). O fortalecimento do devocionário popular, no entanto, não exigia muito dos fiéis, pois a própria doutrina católica já lhes fornecia material suficiente para isso, "basta que eles tenham tido a intenção de proceder de acordo com a Igreja" (GERSON, 1728. Apud HUIZINGA, [s.d.], p. 171). Uma analogia com os peregrinos de Caldeirão e Pau de Colher, que encarnaram santos e santas do universo eclesial e absorveram muito de sua "pura doutrina", transformando-a, modificando-a, tornase inevitável.

O ideal de santidade dos "seguidores de Cristo" encontra, entre os séculos XIII e XIV, certa correspondência com uma corrente evangélica das ordens mendicantes - como a de São Francisco, considerado ele mesmo vítima piedosa do Calvário, reproduzindo na carne a Paixão de Cristo - e dá impulso a um profetismo visionário que corre à margem da instituição. Francisco de Assis, fundador da Ordem dos Frades Menores, considerado por muitos um reformador e um renovador da antiga santidade cristã (VAUCHEZ, 1989, p. 227), simbolizava o ideal máximo de pobreza, desapego ao mundo e castidade.

Mas será apenas no século XV que o fenômeno, fugindo ao domínio da Igreja, assume uma amplitude nunca dantes imaginada. Procissões e sermões de pregadores itinerantes despertavam o povo de forma violenta e incontrolável, levando o público a crises de pranto irreprimíveis (HUIZINGA, [s.d], p. 200). Podemos refletir sobre a 
possibilidade desse novo sentido de santidade ter aportado no Brasil e alcançado os sertões baianos nos séculos subsequentes:

Encontramo-nos em presença de um verdadeiro modelo funcional que caracterizou tanto o Oriente como o Ocidente entre os séculos V e XV, e que por vezes continuou a existir mesmo durante mais tempo. Vamos encontrá-lo intacto em pleno século XVIII em algumas partes da Itália meridional, como a Lucânia, e podíamos observá-lo recentemente ainda na América Latina, em particular no México e no Brasil. (VAUCHEZ, 1987, p. 293)

Além do mais, se, por um lado, o ideal de santidade do medievo tardio mostrou uma capacidade elástica para incorporar diferentes personagens locais e regionais, por outro, não apresentou grande variedade em sua essência fervorosa e ascética, sugerindo um sentido comum de continuidade durante um tempo de longa duração: "Os tipos de santos da Contrarreforma são ainda os mesmos da Alta Idade Média", atesta Huizinga. Outra passagem de autoria de Vauchez resume bem esse período que marcará profundamente a cristandade ocidental e oferece dados importantes para compreendermos o catolicismo itinerante de Pau de Colher, por isso a longa, mas merecida, citação:

Em todo o Ocidente, os únicos religiosos, à exceção dos eremitas, que suscitaram o entusiasmo das multidões são pregadores que consagram a sua vida $\mathrm{e}$ as suas forças ao ministério da palavra. Percorrendo o Ocidente, desde Aragão até a Bretanha e desde a Itália até a Polônia e à Croácia, esses religiosos distinguiam-se claramente do clero a que os fiéis estavam habituados: iam de cidade em cidade, viviam na maior pobreza, mas tinham tempo para se fazer conhecer pelos seus auditores, dado que, muitas vezes, lhes dedicavam um ciclo completo de sermões - por exemplo, durante a Quaresma -, o que lhes dava a possibilidade de se familiarizar com os problemas desta ou daquela cidade e de seus habitantes. As suas intervenções assemelhavam-se mais a grandes espetáculos organizados, verdadeiros meetings ou sessões de happening de que eram, simultaneamente, organizadores e vedetas, do que as prédicas. Falando, em geral, ao ar livre, de um palco de madeira construído para o efeito, eram acompanhados por confessores que tinham o poder de absolver os pecados reservados aos bispos e ao papa e, por vezes, também por grupos de penitentes - os convertidos da véspera que cumpriam uma espécie de peregrinação expiatória - que se autoflagelavam ou se entregavam a outras práticas de devoção antes de o orador tomar a palavra. Este falava, em geral, de grandes verdades necessárias à salvação, mas mais sob um ponto de vista moral do que dogmático. Preocupado em interessar e comover um grande número de ouvintes, procurava, acima de tudo, levá-los a tomar consciência de seus 
pecados e a refletir neles. [...] Mas o desejo de conversão que animava esses santos ia para além da moral individual: conscientes de que viviam num mundo onde os costumes eram pouco influenciados pela mensagem cristã, esforçavam-se por introduzir o Evangelho na vida social. Por isso, não hesitavam em desempenhar as funções de medianeiros, reconciliando as famílias inimigas e os clãs rivais e tentando remediar os males de que sofriam os pobres e os que viviam à margem (VAUCHEZ, 1989, p. 222).

Impossível não enxergar semelhanças entre os perambulantes que percorriam a Europa por esses tempos longínquos e as figuras contemporâneas brasileiras como Antônio Conselheiro (Canudos), José Maria (Contestado), José Lourenço e, logicamente, Severino Tavares, que percorreu diversas cidades dos sertões do São Francisco carregando na memória um conjunto notável de "sermões" que fez conhecer a seus auditores em Pau de Colher. Reportagem de $O$ Jornal dá conta de uma grande "intervenção" de Severino na cidade de Capella (suponhamos seja Capela, em Sergipe), onde foi visto grande ajuntamento popular:

No trem encontro o antigo diretor da viação bahiana o qual me relata o seguinte: "Há cerca de dois annos, encontrei numa praça da cidade de Capella um grande ajuntamento popular. Procurando investigar do que se tratava, vi ali falando ao povo, o mulato Severino, o qual se dizia "enviado do beato Lourenço", substituto do Padre Cícero." Achava-se elle hospedado na fazenda "Caldeiras", cercado das homenagens e das reverências de centenas de pessoas, muitas delas de condição social superior. O "beato" Severino revelava aos circumstantes a missão que o levava àquella cidade: a de salvar todos os quantos o quizessem acompanhar. Prophetizava uma chuva de sangue, que inundaria tudo. Falava com um certo desembaraço, se bem que usasse uma linguagem pobre e mal arranjada, revelando a sua quase completa ignorância. Tive a impressão de que o orador mal saberia, talvez, ler e escrever. Dizia o "beato" Severino que os ricos deveriam dar as suas riquezas aos pobres para encontrar a salvação. Os pobres deveriam todos reunir-se e, em romaria, seguir para junto do "beato" Lourenço a fim de perseguir o antichristo. O meu interlocutor adiantou que mandou chamar Severino, reprehendendo-o duramente pela sua exploração da crendice popular e ameaçando-o de mandar prendêl-o, caso não abandonasse immediatamente a cidade. De facto, o "beato Severino desappareceu logo após, dirigindo-se a Casa Nova. Acredita o meu informante que esse mesmo embusteiro tenha organizado o grupo de fanáticos de Colher de Pau. $^{13}$

${ }^{13}$ Possível infiltração do communismo nas hostes fanáticas do nordeste. $O$ jornal, Rio de Janeiro, 1 de fevereiro de 1938 . 
Falando ao ar livre, Severino queria salvar almas, profetizava o fim dos tempos, desdenhava da riqueza dos coronéis, fazendo do meeting oportunidade única de conversão de fiéis para a causa do Caldeirão. Em Pau de Colher, ele se familiarizou com os problemas do povoado e passou adiante suas "grandes verdades", suas sentenças morais indispensáveis para a purificação dos convertidos. Senhorinho - o São José - formado na mesma disciplina, criado na mesma Lei, procurou então comover o maior número de ouvintes possíveis, e se tornou o único recurso para os que se dispunham a se redimir dos pecados e a refletir sobre eles. A peregrinação expiatória, a autoflagelação, a reconciliação de famílias, enfim, uma série de ações que foi gestada em Caldeirão, sob influência direta de ensinamentos de Padre Cícero, repercutiu de forma notável em Pau de Colher.

\section{Conclusão}

Na perspectiva adotada neste trabalho, a natureza das ações da "gente do sertão" transmite certa coerência e harmonia de sentidos. Os atos de significação religiosa, entre os quais se inclui a dádiva da honraria santoral, fazem parte de uma concepção religiosa muito particular, na qual as representações populares e eruditas perdem um pouco de suas acepções deterministas e se tornam intercambiáveis. Esse processo se deve não apenas às concessões que a Igreja fez para alcançar o coração de seus fiéis, mas também à forma como a tradição católica foi interpretada por diferentes povos em regiões diversas do planeta. Nos longínquos sertões da Bahia, em meio à caatinga, o sertanejo remodelou quadros hagiográficos, fortaleceu suas devoções íntimas e fez de seu tempo um tempo sagrado, divino, extraordinário.

\section{Referências}

AZEVEDO, Thales de. Cultura e situação racial no Brasil. Rio de Janeiro: Civilização brasileira, 1966.

AZZI, Riolando A Sé Primacial de salvador: A Igreja católica na Bahia (1551-2001). 2 v. Petrópolis: Editora Vozes, 2001. 
BOFF, Clodovis. Introdução à mariologia. Petrópolis: Vozes, 2004.

BOFF, Leonardo. São José: a personificação do pai. Campinas: Verus Editora, 2005.

BRANDÃO, Ascânio. Glória e poder de São José. São Paulo: Ave-Maria, 1957.

BRITO, Gilmário Moreira. Pau de Colher: Na letra e na Voz. São Paulo: EDUC/FAPESP, 1999.

CASALEGNO, Alberto. O pluralismo mariológico no Novo Testamento. In: CALIMAN, Cleto (Org.). Teologia e devoção mariana no Brasil. Paulinas: São Paulo, 1989. p. 80116.

CERTEAU, Michel de. A escrita da história. Rio de Janeiro: Forense Universitária, 2000.

COSTA E SILVA, Candido da. Roteiro da vida e da morte: um estudo do catolicismo no sertão da Bahia. São Paulo: Ática, 1982.

DUARTE, Raymundo. Notas preliminares de estudo do movimento messiânico de Pau de Colher. In: COLÓQUIO INTERNACIONAL DE ESTUDOS LUSO-BRASILEIROS, 4, Salvador, 1969. Anais... Salvador: [s.n], 1969.

DUARTE, Raymundo. Um movimento messiânico no interior da Bahia. In: SCHADEN, Egon (Org.). Homem, Cultura e Sociedade no Brasil. Petrópolis: Vozes, 1972. p. 326350. (Seleções da Revista de Antropologia).

DUARTE, Raymundo. O movimento messiânico de Pau de Colher. Cadernos do CEAS, Salvador, p. 99-117, 1997.

ESTRELA, Raimundo. Pau-de-colher: um pequeno Canudos. Salvador: Assembléia Legislativa do Estado da Bahia, 1998.

FACÓ, Rui. Cangaceiros e fanáticos: Gênese e lutas. Rio de Janeiro: Civilização Brasileira, 1963.

FREYRE, Gilberto. Casa-grande e Senzala: formação da família brasileira sob o regime da economia patriarcal. Rio de Janeiro: José Olympio, 1980. 
GAETA, Maria Aparecida J. V. "Santos" que não são santos: estudos sobre a religiosidade popular brasileira. Mimesis, Bauru, v. 20, n. 1, p.57-76, 1999.

GAJANO, Sofia Boeschi. Santidade In: LE GOFF, Jacques e SCHMITT, Jean-Claude. (Orgs.). Dicionário temático do Ocidente Medieval. São Paulo: EDUSC, 2002. v. 2. p. 449-462.

GONÇALVES, Luiz Gonzaga. A irmandade de Pau de Colher (Bahia) e a aspiração por uma terra de liberdade que não cabe num mundo incrédulo. Interfaces de Saberes, Caruaru, v. 3, n.2, p. 41-58, 2002.

GUEIROS, Optato. Lampeão: Memória de um oficial ex-comandante de forças volantes. Recife: [s.n.], 1952.

HAUCK, J. Fagundes. Visão histórica da devoção mariana no Brasil. In: CALIMAN, Cleto (Org.). Teologia e devoção mariana no Brasil. Paulinas: São Paulo, 1989. p. 67-79.

HOORNAERT, Eduardo. A distinção entre "Lei" e "Religião" no Nordeste. Revista Eclesiástica Brasileira, Petrópolis, v. 29, p. 580-606, set. 1969.

HOORNAERT, Eduardo. As relações entre Igreja e Estado na Bahia colonial. Revista Eclesiástica Brasileira, Petrópolis, v. 32, n. 126, p. 275-308, jun. 1972.

HOORNAERT, Eduardo. Modelos de santidade a partir do povo. Revista Concilium, Petrópolis, v. 149, p. 47-57, 1979/9.

LEANDRO, Ana Lúcia Aguiar Lopes. Morte, Drama e Vida dos órfãos de Pau de Colher: rito, memória e identidade - uma história do percurso de voltar a terra. 2008. Tese (Doutorado em Sociologia) - Centro de Humanidades, Universidade Federal de Campina Grande, Campina Grande.

MALVEZZI, Roberto. A história de Pau de Colher - o último grande movimento messiânico do Brasil. s.d. (mimeo).

MALVEZZI, Roberto. Semi-árido - uma visão holística. Brasília: Confea, 2007.

MATTOSO, Kátia M; de Queirós. Bahia, século XIX: Uma província no Império. Rio de Janeiro: Nova Fronteira, 1992. 
MEHLMANN, Dom João. Quatro santas mulheres ao pé da cruz. Revista Eclesiástica Brasileira, Petrópolis, v. 23, n.1, p.134-136, mar.1953.

MELLO, Maria Alba Guedes Machado. O movimento messiânico de Pau de Colher (uma reconstituição histórica). Revista da Bahia, Salvador, v. 33, n.19, p. 52-59, 1991.

NARBER, Gregg R. Imagined Futures in conflict: Brazil's Revolution of 1930, The Modernizing Estado Novo, and Millenarian Caldeirão and Pau de Colher. In: INTERNATIONAL CONGRESS OF THE LATIN AMERICAN STUDIES ASSOCIATION (LASA), 28, 2009, Rio de Janeiro. Anais... Rio de Janeiro: [s.n.], 2009.

OLIVEIRA, Ruy Bruno Bacelar de. De Caldeirão a Pau de Colher: a guerra dos caceteiros. Vitória da Conquista: RBB, 1998.

PAIVA, Jorge O`Grady. Missão, Grandeza, Culto e Atualidade de S. José. Revista Eclesiástica Brasileira, Petrópolis, v. 14, n..1, p.1-6, mar. 1954.

PEREIRA DE QUEIROZ, Maria Isaura. O messianismo no Brasil e no mundo. São Paulo: Dominus/Edusp, 1965.

POMPA, Maria Cristina. Memória do fim do mundo: para uma leitura do movimento Sócio-religioso de Pau de Colher. 1995, 160 f. Dissertação (Mestrado em Antropologia) Instituto de Filosofia e Ciências Humanas, Universidade Estadual de Campinas, Campinas.

SERBIN, Kenneth P. Padres, celibato e conflito Social; Uma história da Igreja católica no Brasil. São Paulo: Companhia das Letras, 2008.

SILVA, Andréia Cristina Lopes Frazão. Hagiografia e poder nas sociedades ibéricas medievais. Revista de Ciências Humanas, Curitiba, n. 10, PP. 135-172, 2001.

SILVA, Antenor de Andrade. Cartas do Padre Cícero (1877-1934). Salvador: Ed. E. P. Salesianas, 1982.

SILVA, Francivaldo Mendes da. Pau de Colher: narrativas de luta e fé no sertão da Bahia. 2008, 155f. Dissertação (Mestrado) - Centro de Filosofia e Ciências Humanas, Univercidade federal de Pernambuco, Recife.

SILVA, José Ariovaldo da. São José: entre a devoção e a liturgia. Grande Sinal, 
Petrópolis, v. 42, p.133-146, mar/abr de 1988.

TAVARES, Luis Henrique Dias. História da Bahia. São Paulo: Salvador: EDUNESP/ EDUFBA, 2008.

TAVARES, Maurino Cezimbra. Fatos históricos de criminalidade: estudo médico social. Trabalho apresentado ao Instituto Baiano de Medicina. Salvador: Imprensa Oficial da Bahia, 1954.

VAINFAS, Ronaldo e SOUZA, Juliana Beatriz Almeida de. Nossa Senhora, o fumo e a dança. In: NOVAES, Adauto (Org.). A outra margem do ocidente. São Paulo: Companhia das Letras, 1999. p. 201-221.

VAUCHEZ, André. A santidade. In: Enciclopédia Einaudi. Lisboa: Imprensa Nacional/Casa da Moeda, 1987. p. 287-300.

VAUCHEZ, André. O santo. In: LE GOFF, Jacques (Org.) O homem medieval. Lisboa: Presença, 1989. p. 211-230.

VAUCHEZ, André. A espiritualidade na Idade Média Ocidental: Séculos VIII a XIII. Rio de Janeiro: Jorge Zahar Editor, 1995. 